Research Report No. 10/2013

\title{
Canadian Mining Companies and Domestic Law Reform: A Critical Legal Account
}

Charis Kamphuis

Follow this and additional works at: http:/ / digitalcommons.osgoode.yorku.ca/clpe

\section{Recommended Citation}

Kamphuis, Charis, "Canadian Mining Companies and Domestic Law Reform: A Critical Legal Account" (2013). Comparative Research in Law \& Political Economy. Research Paper No. 10/2013.

http://digitalcommons.osgoode.yorku.ca/clpe/259 


\section{OSGOODE}

OSGOODE HALL LAW SCHOOL YOR K U N I VERSITY

\section{OSGOODE HALL LAW SCHOOL}

Comparative Research in Law \& Political Economy

RESEARCH PAPER SERIES

Research Paper No. 10/2013

\section{Canadian Mining Companies and Domestic Law Reform: A Critical Legal Account}

Charis Kamphuis

Editors:

Peer Zumbansen (Osgoode Hall Law School, Toronto, Director Comparative Research in Law and Political Economy)

John W. Cioffi (University of California at Riverside)

Leeanne Footman (Osgoode Hall Law School, Toronto, Production Editor)

Comparative Research in Law \& Political Economy 


\title{
Articles
}

\section{Canadian Mining Companies and Domestic Law Reform: A Critical Legal Account ${ }^{*}$}

\author{
By Charis Kamphuis ${ }^{* *}$
}

\section{A. Introduction \& Research Context}

In the last decade, Canada has become the most important home jurisdiction for mining companies operating globally. Certain Canadian NGOs, faith groups and labor unions ${ }^{1}$ argue that these activities systematically give rise to conflicts between companies and local communities in circumstances where companies frequently enjoy effective impunity for the human rights violations they may commit. This assessment has prompted these groups and other likeminded actors to advocate for a series of law reform proposals.

This article offers a critical legal account of these law reform efforts, undertaken between 2005 and 2012, together with the government's response, introduced in 2009. It begins in Part B by introducing the social and economic context that forms the backdrop of these efforts. This consists of a description of the Canadian foreign mining sector and some of the associated social conflicts. Extractive activities and conflicts in Latin American are profiled in particular given the significance of that region for Canadian mining companies. The relevant proposals for legal reform in Canada are then reviewed in Part C in terms of three periods. In the first, federal advisors made proposals that attempted to reconcile private and public approaches to regulation. In the second, the federal government introduced a corporate social responsibility (CSR) policy predicated on volunteerism. And in the third period, three individual Members of Parliament have tabled private members' bills, each representing very different private and public approaches to regulation.

\footnotetext{
* This paper is based on a presentation made at the Fifth CLPE conference at Osgoode Hall Law School (Toronto), 1-2 March 2012, entitled "Transnational Private Regulatory Governance: Regimes, Dialogue, Constitutionalization". This paper is also an initiative of the Justice and Corporate Accountability Project (JCAP). Its compilation benefited from conversations with Alejandro Campos Garcia, comments provided by Professor Shin Imai and research conducted by Umair Abdul. All errors are the sole responsibility of the author.

${ }^{* *}$ B.A. (Toronto), LL.B. (Saskatchewan), LL.M. (Osgoode), Doctoral Candidate, Osgoode Hall Law School (York University), Canada. Email: chariskamphuis@osgoode.yorku.ca.

${ }^{1}$ CANADIAN Network On CoRporate ACCOUNTABILITY, Our Members, available online at: http://cnca-rcrce.ca/aboutus/members/ (last accessed: 1 December 2012).
} 
Following this review, each reform project is analyzed in Part D in terms of the regulatory vision it presents and the conception of the state, the corporation, and civil society that it advances. In conclusion, this article's place within its broader research context is explored. To date, the Federal government has declined to enact legislation that would specifically regulate the activities of Canadian mining companies operating abroad. In the absence of such a regime, advocates interested in pursuing legal recourse in Canada are presently engaging with an ad hoc mix of private and public legal mechanisms to pursue corporate accountability on behalf of affected communities. The present article is part of a larger project that examines this engagement and inquires into the theoretical, political and strategic considerations that might guide this activism. Among the broader questions at stake is that of the nature of the relationship between legal form and substance in the context of private or public law activism. This may be particularly of interest to those concerned with the question of how the private or public nature of the legal forum might shape the substance of activists' legal and political struggles.

\section{B. Canadian Mining Abroad: Social \& Economic Context}

\section{The Canadian Mining Sector: Global and National Economic Significance}

Canadian mining companies have historically had a strong global presence and until very recently, their outward investment has consistently exceeded inward investment levels. ${ }^{2}$ In the last two decades, Canadian stock exchanges have come to dominate the global mining industry. As of 2012, Canadian stock exchanges listed more mining companies than the exchanges of any other country in the world and Canadian-listed companies conducted about $40 \%$ of all mineral exploration globally. ${ }^{3}$ This market activity is concentrated on the Toronto Stock Exchange (TSX) and the TSX Venture Exchange (TSXV), currently home to $58 \%$ of the world's publicly traded mining companies. ${ }^{4}$ These two exchanges are also the largest source of equity capital for global mining exploration and production. From 19992011 , on average they facilitated over $80 \%$ of all global mining equity financings, and in 2011 and 2012 that number rose to $90 \% .^{5}$

\footnotetext{
${ }^{2}$ Paul Stothart, F \& F 2011: Facts \& Figures of the Canadian Mining Industry, THE MINING AsSOCIATION OF CANADA, 82, available online at: http://www.mining.ca/www/media lib/MAC Documents/F\&F2011-English.pdf (last accessed: 1 December 2012).

${ }^{3}$ As of December 2011, there were 1646 mining companies listed on the TSX/V. The majority of these were exploration companies: TMX, A CAPITAL OPPORTUNITY: MINING (2012), 11, 17, 24, available online at: http://www.tmx.com/en/pdf/Mining_Presentation.pdf (last accessed: 1 December 2012). [TMX, "Mining"]. However, 16 of the "top 100" mining companies in the world are Canadian, which is second only to China's 18 companies in this same category, see Stothart, supra note 2, at 81.

${ }^{4} \mathrm{TMX}$, "Mining", supra note 3, at 13.

${ }^{5}$ Id. at $19,21$.
} 
Just as the activities of these companies are significant globally, they are also important for Canadian capital markets generally. Among Canada's goods-producing sectors, mining companies listed on Canadian stock exchanges are the largest single group of outward investors. This has grown from \$13.5 billion in investments in 1990 to \$58 billion in 2010, with a historic high of $\$ 66.2$ billion in 2008 . $^{6}$ This sector accounts for a sizable portion of all Canadian direct investment abroad, at over $12 \%$ in 2005 and 9.4\% in $2010 .^{7}$

Almost half of all mineral exploration projects held by TSX/V companies are outside of Canada $^{8}$ and Latin America is one of the most significant regional destinations for this investment. According to statistics from 2009 and 2010, approximately 50\% of all Canadian mining assets abroad are invested in Latin America and the Caribbean ${ }^{9}$ and there are 286 TSX/V listed mining companies operating in South America alone. ${ }^{10}$ Moreover, Canadian mining investment in this region appears to be growing. In 2010, companies on the TSX/V raised a record amount of capital for projects in Latin America ${ }^{11}$ and in 2011 projects in South America received the largest share of the total amount of mining equity capital raised. ${ }^{12}$

In sum, Canadian mining companies are major global players and Canadian capital markets play a crucial role in facilitating the investment activity that drives the global mining industry. In this context, Latin America is one of the most important regional destinations for Canadian mining investment. Taken together, these activities are also significant for Canada in that they form an important part of Canada's overall foreign investment activity.

\section{Canadian Mining \& Social Conflict in Latin America}

Any review of law reform efforts must begin by describing "the problem" that such reforms seek to address. In many policy matters this can be controversial and the activities of Canadian mining companies abroad is no exception. In this context, it is useful to begin

\footnotetext{
${ }^{6}$ Stothart, supra note 2 , at 91.

${ }^{7}$ The relative decline in recent years, namely, from $15 \%$ in the 1990 s to about $10 \%$ in the last decade, is due to the increased outward investment in the energy and financial sectors, see Stothart, supra note 2 , at 82.

${ }^{8}$ TMX, "Mining", supra note 3, at 23.

${ }^{9}$ Natural Resources Canada, The Geographical Distribution of Canada's Mining Assets, available online at: http://www.nrcan.gc.ca/minerals-metals/publications-reports/4425 (last accessed: 1 December 2012).

${ }^{10} \mathrm{TMX}$, supra note 3 , at 32 .

${ }^{11} \mathrm{TMX}$, supra note 3 , at 16.

${ }^{12}$ TMX, supra note 3, at 29. The region of Asia tied with South America for this top position.
} 
with sources that share a relatively high degree of consensus. The activities of Canadian mining companies were intensively studied by the Advisory Group of the Canadian National Roundtables on Corporate Social Responsibility and the Extractive Industry in Developing Countries, a group of experts representing industry, NGOs and academia. In its consensus report, this group summarized the concerns at issue in terms of: "environmental concerns; community relations; human rights; security and armed conflict; labor relations; indigenous peoples' rights; compatibility of resource development with national and local economic priorities; benefit sharing with local communities; ineffective legal systems and the potential for corruption." ${ }^{13}$

The Advisory Group developed this list in part on the basis of information provided by a large number of civil society organizations in Canada and internationally ${ }^{14}$ that are dedicated to documenting the concerns expressed by numerous communities located in countries where Canadian mining companies operate. This grassroots work is prolific and in many cases it involves allegations that are highly contentious. At the same time, it has given rise to a handful of legal proceedings in Canada, together with a small concentration of academic writing and empirical research. Of course even these accounts, presented in the formal settings of law and academia, are also contested. To date no court has considered a case based on its substantive merits for the reason that mining company defendants have successfully raised preliminary objections that prevented these cases from moving forward.

This review draws on this relatively small body of published academic writing and legal claims to provide some specific examples of "the problem" associated with the activities of Canadian mining companies abroad. It maintains a focus on Latin America, partly because of the economic importance of this region, evidenced above, but also due to the fact that the public record, as generated by legal activism and academic writing, is arguably greater in relation to Canadian mining in Latin America than in any other regions. While this review is brief and non-exhaustive, it nonetheless offers a preliminary sketch of the nature of the social conflicts at issue.

Perhaps not surprisingly, concerns regarding current or potential environmental damage are a significant underlying factor in many of the conflicts attributed to Canadian mining.

\footnotetext{
${ }^{13}$ Advisory Group Report, National Roundtables on Corporate Social Responsibility (CSR) and the Canadian Extractive Industry in Developing Countries, PROSPECTORS AND DEVELOPERS ASSOCIATION Of CANADA (PDAC), 4-5 (Mar. 29, 2007), available online at: http://www.pdac.ca/pdac/misc/pdf/070329-advisory-group-report-eng.pdf (last accessed: 1 December 2012).

${ }^{14}$ The Advisory Group's Report was based on submissions made during the National Roundtables. In total, the Advisory Group heard 156 oral presentations and received 104 written submissions. Of these oral presentations, 61 were from civil society, 33 from industry, 15 from labor organizations, 31from academics and research institutes, and 16 from members of the public without a stated affiliation, see Advisory Group Report, supra note 13, at $i$.
} 
The most famous case in this category arose from an environmental catastrophe caused by the collapse of a tailings dam in 1995 at the Omai Gold Mine in Guyana, owned by Cambior. ${ }^{15}$ While this is the only case brought in Canada to date on the basis of actual environmental damage, there is documentation of growing concern for potential environmental damage. This is expressed through the emerging practice of the local community referendum, which generally consists of a formal opportunity, organized by and for community members, to vote either for or against a proposed project. With regard to Canadian mining companies, there are three well-documented examples to date in Latin America (in Peru, Guatemala and Argentina), all resulting in the popular rejection of the proposed project. ${ }^{16}$ While these votes have occurred in the context of varying domestic legal frameworks and their legal implications are contested, ${ }^{17}$ they have had important political consequences.

The phenomenon of community referenda raises the issue of the meaningful participation and consent of local communities to mining projects. This in turn feeds into another significant underlying factor in Canadian mining conflicts in Latin America, namely the failure to respect communal and individual land and property rights. While allegations of this nature are numerous, there are several cases where it has been possible to collect

\footnotetext{
${ }^{15}$ For detailed discussions of this case, see Kernaghan Webb, CSR and the Law: Learning from the Experience of Canadian Mining Companies in Latin America, in GovernANCE ECOSYSTEMS: CSR IN THE LATIN AMERICAN MINING SECTOR 47, 48-9 (Julia Sagebien \& Nicole Marie Lindsay eds., 2011); Craig Scott \& Robert Wai, Transnational Governance of Corporate Conduct through the Migration of Human Rights Norms: The Potential Contribution of Transnational Private Litigation, in TRANSNATIONAL GOVERNANCE AND CONSTITUTIONALISM 287, 297-303 (Christian Joerges, IngerJohanne Sand \& Gunther Teubner eds., 2004).

${ }^{16}$ Brant McGee, The Community Referendum: Participatory Democracy and the Right to Free, Prior and Informed Consent to Development, 27 BERKELEY J. INT'L L. 570 (2009). In 2002 the community of Tambogrande, Peru voted against a gold mining project proposed by Manhattan Minerals. It is reported that $98 \%$ of the $73 \%$ of eligible voters who participated voted against the project, see McGee, The Community Referendum at 604 . In 2005 the community of Esquel, Argentina voted against a project proposed by Meridian Gold. It is reported that $81 \%$ of $75 \%$ of eligible voters who participated voted against the project, see McGee, The Community Referendum at 615; Mariana Walter \& Joan Martinez-Alier, How to be Heard When Nobody Wants to Listen: Community Action against Mining in Argentina 30 CAN. J. OF DEV. STU. 281 (2010). In 2005 indigenous communities in Sipacapa, Guatemala voted against the activities of Marlin Mine owned by Goldcorp. It is reported that 11 of 13 villages voted against mining, casting 2486 votes against the mine with only 35 votes in favour, see McGee, The Community Referendum at 619.

${ }^{17}$ To date the primary impact of these referenda have been political. However, several authors have argued that these referenda, particularly when undertaken by indigenous communities, have legal weight in international law. One argument is that these referenda carry legal weight in international law under the rubric of the right to free, prior and informed consent, see McGee, The Community Referendum at 635. Another argument is that the Guatemala referendum was an expression of Indigenous law, made with the authority that arises from the inherent rights that come with being an indigenous people, see Shin Imai, Ladan Mehranvar \& Jennifer Sanders, Breaking Indigenous Law: Canadian Mining in Guatemala, 6 InDIGENOUS L.J. 1, 17 (2007). For an argument that links the Guatemala referenda to the right to self-determination, see Tara Ward, The Right To Free, Prior, And Informed Consent: Indigenous Peoples' Participation Rights Within International Law, 10 NW. J. INT'L H.R. 54
} (2011). 
extensive supporting documentation. The Marlin Mine in Guatemala, owned by Goldcorp, is accused of failing to properly consult with local communities prior to mine development and of coercing landowners into selling their property to the company. ${ }^{18}$ Also in Guatemala, the Canadian owners of the El Estor Mine have been accused of ignoring the land claims of indigenous communities and of participating in the violent eviction of community members. ${ }^{19}$ Finally, the La Platosa Mine in Mexico, owned by Excellon Resources, is accused of failing to respect its land rental agreement with local communal landowners. $^{20}$

These bases for community opposition to Canadian mining frequently result in conflicts that include acts of violence against community members, and particularly against prominent leaders. It is alleged that in 2006 the employees of a private security company, contracted by Copper Mesa, attacked unarmed members of a community in Junin, Ecuador who opposed the company's proposed project. ${ }^{21}$ The community referenda in Peru and Guatemala, referenced above, were both accompanied by violence. Community leaders were assassinated in the context of both referenda, and in Guatemala police and army officers killed an individual at a public protest. $^{22}$ In relation to the El Estor Mine in

${ }^{18}$ Irene Sosa, Responsible Investment Case Studies: Newmont and Goldcorp, in 201, 207 GOVERNANCE ECOSYSTEMS: CSR IN THE LATIN AMERICAN MINING SECTOR (Julia Sagebien \& Nicole Marie Lindsay eds., 2011); Imai, Mehranvar \& Sanders, Breaking Indigenous Law, supra note 17; Ward, The Right To Free, Prior, And Informed Consent, supra note 17 at 75 . These allegations were the subject of a petition to the Inter-American Commission for Human Rights, see Communities of the Maya People (Sipakepense and Mam) of the Sipacapa and San Miguel Ixtahuacán Municipalities in the Department of San Marcos, Guatemala, PM 260-07, Inter-Am. Comm'n H.R., (20 May 2010), available at: http://www.cidh.oas.org/medidas/2010.eng.htm (last accessed: 1 December 2012).

${ }^{19}$ Ownership of the El Estor Mine changed hands between three Canadian companies between the early 1960s and 2008 before being sold to a private company headquartered in Cyprus in 2011. For instance, see Shin Imai, Bernadette Maheandiran \& Valerie Crystal, Accountability Across Borders: Mining in Guatemala and the Canadian Justice System, in TRANSNATIONAL CoRporations, Human RIGHTS AND ENVIRONMENTAL JUSTICE IN LATIN AMERICA (Obi Aginam, ed., forthcoming).

${ }^{20}$ Complaint Submitted to the Canadian National Contact Point Pursuant to the OECD Guidelines for Multinational Enterprises Concerning: The Operations of Excellon Resources Inc. at the La Platosa Mine in the Ejido "La Sierrita", Durango State, México (29 May 2012). Excellon is also accused of systematically undermining the efforts of its employees to organize a democratically elected labour union through acts of union intimidation and violations of workers' rights to freedom of association. See press release and accompanying documents at: Mining Watch Canada, "Mexican Workers, Landowners File Second Complaint Against Canadian Mining Company Excellon Resources" Press Release (29 May 2012), available online at: http://www.miningwatch.ca/news/mexicanworkers-landowners-file-second-complaint-against-canadian-mining-company-excellon (last accessed: 1 December 2012).

${ }^{21}$ Some of these violent confrontations were caught on film: see Malcolm Rogge, Under Rich Earth, see documentary website at $\langle$ http://underrichearth.ryecinema.com/?page_id=114>. They were also the subject of an unsuccessful lawsuit in Canada: Piedra v. Copper Mesa Mining Corporation: Statement of Claim, (3 March 2009), available at: http://www.ramirezversuscoppermesa.com/ (last accessed: 1 December 2012); Piedra v. Copper Mesa Mining Corporation, 2011 ONCA 191.

${ }^{22}$ McGee, The Community Referendum, supra note 16, at 574. 
Guatemala, since 1969 there have been numerous assassinations of community leaders, most recently in 2009. ${ }^{23}$ The El Estor Mine is also the focus of one of the most disturbing allegations of violence against a Canadian mining company to date. It is alleged that in 2007, police, military, and the mine's security personnel raped ten Mayan women while undertaking land evictions in favor of the company. ${ }^{24}$

These micro-level accounts of the use of violence in order to protect the interests of Canadian mining companies resonate with the general observations of international human rights bodies. In 2010, the United Nations Special Rapporteur on the Situation of Human Rights Defenders reported that private corporations are allegedly impeding the activities of human rights defenders working on issues related to the exploitation of natural resources. The Rapporteur noted instances where security guards employed by mining companies allegedly committed acts of violence against human rights defenders concerned with the negative impacts of these activities. ${ }^{25}$ Similarly, in 2011 the InterAmerican Commission on Human Rights observed that violence against defenders of the environment has become more pronounced where there are serious tensions between the supporters of extractive industries, and those sectors that resist the implementation of projects in order to prevent environmental harm. ${ }^{26}$

In sum, the legal and academic accounts touched upon in the above review can by synthesized in terms of three key potential sources of social conflict between Canadian mining companies and communities in Latin America. First, conflicts can arise were communities suspect actual or potential environmental damage. Second, conflicts can originate in a lack of consent and inadequate community participation in project development. Finally, violations of communal or individual property rights and/or disregard for land claims may lead to conflict. When these three concerns remain unaddressed and conflicts occur, there is a risk that community opposition to mining will be met with significant violence and repression.

\footnotetext{
${ }^{23}$ For an overview of these assassinations, see Imai, Maheandiran \& Crystal, Accountability Across Borders, supra note 19. The 2009 assassination is the basis of a civil lawsuit currently underway in Canada, see Choc v. HudBay Minerals Inc., CV-10-411159 (Ont. Sup. Ct. J. filed Sept. 24, 2010), available online at: http://www.chocversushudbay.com/wp-content/uploads/2010/11/Second-Amended-Fresh-as-Amended-Chocv.-HudBay-FILED.pdf (last accessed: 1 December 2012).

${ }^{24}$ These alleged rapes are the basis of a civil lawsuit currently underway in Canada, see Caal v. Hudbay, CV-11423077 (Ont. Sup. Ct. J. filed Mar. 28, 2011), available online at: http://www.chocversushudbay.com/wpcontent/uploads/2010/11/Amended-Statement-of-Claim-Caal-v.-HudBay-FILED.pdf (last accessed: 1 December 2012).

${ }^{25}$ Special Rapporteur on the Situation of Human Rights Defenders, Human rights defenders, ๆ 9-10, U.N. Doc. A/65/223 (Aug. 4, 2010).

${ }^{26}$ Second Report on the Situation of Human Rights Defenders in the Americas, Inter-Am. Comm'n H.R., OEA/Ser.L/V/II, doc. 66, ๆ 312 (Dec. 31, 2011).
} 


\section{Resource Extraction \& Law Reform Efforts in Canada}

Communities' concerns and the associated risks of violence form the social context that has compelled civil society actors to advocate in favor of law reform in Canada. While these law reform efforts are multifaceted, they have nonetheless been dominated by a fundamental struggle between two models. Certain civil society actors have advocated for Canadian government regulation and enforceable laws, while certain industry representatives have taken the position that voluntary mechanisms represent the best governance model.

The struggle in Canada between these two approaches, which has largely taken place since the early 2000s, can be understood in terms of three main, yet somewhat overlapping, periods. In the first period, federal government advisors proposed regulatory models that attempted to reconcile public regulation and private voluntary governance models. Following this, the federal government introduced its CSR policy in the form of a private voluntary model that is facilitated by designated government actors. In the third period, federal Members of Parliament introduced three different private members bills, respectively representing public law, private law and voluntary approaches to regulation. The proposals developed in each of these periods are reviewed below with a focus on their regulatory features.

\section{Federal Advisors: Reconciling Private Volunteerism and Public Regulation?}

After civil society activists succeeded in bringing concerns regarding the conduct of Canadian mining companies abroad to the attention of federal lawmakers, the Parliamentary Sub-committee on Human Rights and International Development held periodic hearings into the matter. In 2005, the Sub-committee drafted a report entitled Mining in Developing Countries: Corporate Social Responsibility, ${ }^{27}$ which was subsequently adopted by the Standing Committee on Foreign Affairs and International Trade (SCFAIT) and submitted to Parliament.

The SCFAIT Report called on the Government of Canada to "put in place stronger incentives to encourage Canadian mining companies to conduct their activities outside of

\footnotetext{
${ }^{27}$ House of Commons Standing Committee on Foreign AfFaiRs And InTernational Trade, Mining in Developing Countries: Corporate Social Responsibility, Parl. 38th Sess. 1, Rep. 14th (June 2005), available online at: http://www.resourceconflict.org/Foreign\%20Affairs\%20Committee\%20\&\%20Mining.pdf (last accessed: 1 December 2012). This report was compiled on the basis of the committee's recent round of hearings in continuation of the committee's compilation of evidence over several years related to the activities of Canadian mining companies in developing countries, id. at 1.
} 
Canada in a socially and environmentally responsible manner and in conformity with international human rights standards." ${ }^{28}$ The Committee urged that such measures "must include" conditioning federal government financial and political support ${ }^{29}$ for companies on their adherence to "clearly defined corporate social responsibility and human rights standards". ${ }^{30}$ Further, the Committee urged the government to "establish clear legal norms in Canada to ensure that Canadian companies and residents are held accountable when there is evidence of environmental and/or human rights violations". ${ }^{31}$

These core recommendations are notable for the particular approach to public regulation that they promote. The SCFAIT Report envisions a role for the federal government that evaluates mining companies' compliance with a set of normative standards, prior to extending political or financial support. In this regard, it defines "financial support" as project loans made with public funds, primarily through Export Development Canada. Further, the Committee proposes that this preliminary conditionality be accompanied by a complaint or investigation mechanism with the enforcement power to ensure accountability, in the form of the withdrawal of government support, for violations of these standards. Finally, while the Report references CSR standards, it's overall language appears to propose public international human rights law, such as international human rights treaties, as the basis for developing the enforceable standards it calls for.

In addition to proposing a public regulation approach, the SCFAIT Report calls on the federal government to actively promote the enforcement capacity of certain private transnational mechanisms. Specifically, the Report calls upon the government to advocate for a model of mandatory compliance with regard to the, at-present voluntary, OECD Guidelines for Multinational Enterprises. It also calls on the Government of Canada to advocate for a model among international financial institutions (IFIs) where project financing is made contingent on adherence to international human rights standards. ${ }^{32}$

In response to the 2005 SCFAIT report, in 2006 the Department of Foreign Affairs and International Trade (DFAIT) established the National Roundtables on Corporate Social

\footnotetext{
${ }^{28}$ Id. at 2

${ }^{29}$ The Report defined this as including export and project financing together with services offered by Canadian missions abroad, see id. at 2.

${ }^{30}$ Id. The Report suggested that compliance could be demonstrated through the mechanism of human rights impact assessments.

${ }^{31}$ Id. at 3.

${ }^{32}$ Certain IFIs, such as the World Bank and those banks that have signed onto the Equator Principles, have CSR policies. However, as of 2010, there was no known example of a case where an IFI had withdrawn project financing on the basis of a violation of these policies: Catherine Coumans, Alternative Accountability Mechanisms and Mining: The Problems of Effective Impunity, Human Rights, and Agency 30 C.J.D.S. 27, 36, (2010).
} 
Responsibility (CSR) and the Extractive Industry in Developing Countries. To support the Roundtables, DFAIT convened an Advisory Group of experts from academia, labor, civil society, the socially responsible investment community, and industry. After participating in roundtables in four Canadian cities, the Advisory Group drafted a final report with consensus recommendations for the creation of a CSR Framework by the Government of Canada. ${ }^{33}$ According to one Advisory Group member, achieving a consensus regarding the regulatory component of this Framework required the negotiation of an accountability mechanism that struck a middle ground between the position of government and industry in favour of "pure volunteerism", and the push from civil society members for mandatory standards and law reform to make sanctions and remedies available in Canadian courts. ${ }^{34}$

The model of regulation ultimately proposed by the Advisory Group contained two key components of interest. ${ }^{35}$ First, it involved the development of a set of Canadian CSR standards of conduct and reporting obligations. However, it circumscribed the sources of these norms to include only those international frameworks that result from "multistakeholder and multilateral dialogue". This caveat refers to private transnational norms designed with the joint participation of civil society actors, states, and industry. Concretely, the Advisory Group sanctioned the International Finance Corporation (IFC) Performance Standards and the Voluntary Principles on Security and Human Rights as the only appropriate sources of standards, in addition to the OECD Guidelines, already endorsed by the Government of Canada. ${ }^{36}$ As such, the use of public international human rights law and treaties as a source of standards was effectively precluded from the proposed Canadian CSR Framework. Rather, the Report states that the application of the private transnational standards named above must "observe and enhance respect for" the principles of public international human rights law "that are within the sphere of control of companies". ${ }^{37}$

Second, the Advisory Group's proposed model included a fact-finding and accountability component with two key features: an ombudsman and a review committee. In this concept, the independent ombudsman office would be empowered to investigate and report on complaints with respect to Canadian extractive companies operating in

\footnotetext{
${ }^{33}$ ADVISORY GROUP REPORT, supra note 13.

${ }^{34}$ Coumans, supra note 32 , at $40-41$.

${ }^{35}$ A third component, albeit less salient from a regulatory perspective, related to the formation of a multistakeholder Canadian Extractive Sector Advisory Group to advise government on the implementation and further development of the Canadian CSR Framework, see ADVISORY GROUP REPORT, supra note 13, at iii.

${ }^{36}$ Id. at iv-v.

${ }^{37}$ Id. at v. In its Report, the Advisory Group acknowledges that the initial recommended framework falls short of addressing the full range of issues of concern regarding extractive industry, particularly with regard to human rights, see id. at iv.
} 
developing countries. ${ }^{38}$ This role would feed into the mandate of a tripartite Compliance Review Committee with the power to consider the ombudsman's investigations in order to make determinations and recommendations regarding the nature and degree of company non-compliance with Canadian CSR Standards. In cases of serious failure to comply, and when steps to bring the company into compliance had failed, the CSR framework contemplated that the Government of Canada should sanction the company by withdrawing financial and/or non-financial support. ${ }^{39}$ Like the SCFAIT Report, the Advisory Group defined these forms of support in terms of financial support from Export Development Canada (EDC) and political support from diplomatic trade missions, defined as support that goes beyond ordinary consular services by promoting a Canadian company or its interests in a foreign country.

\section{The Federal CSR Policy: The Advantage of Canadian Volunteerism}

The Government of Canada waited two years to respond to the Advisory Group Report. Then, in 2009, it announced its policy "Building the Canadian Advantage: A Corporate Social Responsibility Strategy for the Canadian International Extractive Sector". This policy represents a radical embrace of volunteerism that sharply contrasts the proposals tabled in the SCFAIT and the Advisory Group Reports.

The overall objective of the federal policy is to "improve the competitiveness" of the sector by enhancing companies' abilities to manage social and environmental risks. ${ }^{40}$ To this end the policy operates on the basis of four pillars. First, it supports initiatives to enhance the capacities of developing countries to manage the development of extractive activities and improve opportunities for economic development. Second, it endorses four voluntary transnational performance guidelines: the IFC Performance Standards, the Voluntary Principles, the Global Reporting Initiative (GRI), and the OECD Guidelines. Third, it creates a Centre for Excellence in CSR, and finally, it creates the Office of the Extractive Sector Corporate Social Responsibility Counselor, who is a special advisor to the Minister for International Trade. This Office has the mandate to administer the policy's regulatory component.

The Office of the CSR Counselor is mandated to review the CSR practices of Canadian companies operating outside of Canada according to a five-step process that, upon the

\footnotetext{
${ }^{38}$ Id. at vi-vii.

${ }^{39}$ /d. at xii-xiii.

${ }^{40}$ Department of Foreign Affairs and International Trade CANAdA, The Government of Canada's CSR Strategy (Mar. 2009), available online at: http://www.international.gc.ca/csr counsellor-conseiller rse/About us-

A propos du bureau.aspx?view=d (last accessed: 1 December 2012).
} 
submission of a request for review, offers eligible parties informal mediation, followed by the option of formal mediation. ${ }^{41}$ It states that an "individual, group or community" who "reasonably believes" that they have been adversely affected by the activities of a Canadian extractive sector company, for the reason that they are inconsistent with the endorsed guidelines, is eligible to request a review. At the same time, a Canadian company can submit a request for review to the Office if it "believes" that "an identifiable party" has made unfounded allegations against it. In both cases the process is voluntary and the participants can withdraw at any time. The Office states that its process is not adjudicative or investigative, rather it aims to promote dialogue, problem solving and conflict resolution.

The Office opened in March 2010 and began receiving requests for review in October of that year. To date, the Office has received only three requests for review in two years. ${ }^{42} \mathrm{~A}$ Mexican NGO and labor union jointly requested the first review in relation to Excellon Resources. This review failed to yield results because Excellon abruptly withdrew from the process before proceeding to the dialogue stage. ${ }^{43}$ The Office received its second request for review from organizations in Mauritania concerned about First Quantum Minerals' mine, but it closed this review shortly thereafter at the "informal mediation" phase for the reason that the requesters had not pursued the available "site level grievance mechanism". ${ }^{44}$ Two Argentinean NGOs The Office submitted a third request for review in relation to a project owned by McEwen Mining. Like Excellon, McEwen Mining withdrew from the process before it could proceed from the "information mediation" phase to a "facilitated dialogue". 45

\footnotetext{
${ }^{41}$ Department of Foreign AfFaiRS ANd International TRAde CANADA, Review Process of the Office of the Extractive Sector Corporate Social Responsibility (CSR) Counsellor, available online at: http://www.international.gc.ca/csr counsellor-conseiller rse/assets/pdfs/info\%20brochure\%20Nov1.pdf (last accessed: 1 December 2012).

${ }^{42}$ Office Of The EXtractive Sector Corporate Social Responsibility (CSR) Counselor, 2011 Annual Report to Parliament (Nov. 2011), available online at: http://www.international.gc.ca/csr_counsellorconseiller rse/assets/pdfs/2011_report to parliament-eng.pdf (last accessed: 1 December 2012).

${ }^{43}$ Id. at 22. OfFICE OF THE EXTRACTIVE SECTOR CORPORATE SOCIAL RESPONSIBILITY (CSR) COUNSELOR, Closing report-Request for review file \#2011-01-MEX (Oct. 2011), available online at: http://www.international.gc.ca/csr counsellorconseiller rse/assets/pdfs/Closing report MEX.pdf (last accessed: 1 December 2012). The Counselor stated that in her opinion Excellon's decision to withdraw represented a significant missed opportunity and that the request for review had every reason to move fruitfully to a structured dialogue were it not for Excellon's withdrawal, see id. at 2-4.

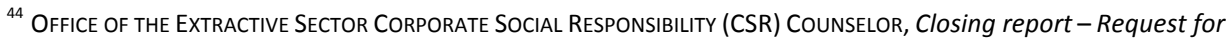
review file \#2011-02-MAU, 4 (Feb. 2012), available online at: http://www.international.gc.ca/csr counsellorconseiller rse/assets/pdfs/2011-02-MAU closing report-rapport final-eng.pdf (last accessed: 1 December 2012).

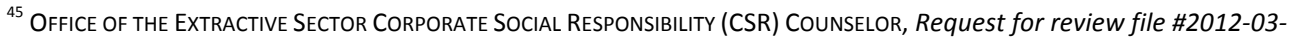
ARG - Closing Report (Oct. 2012), available online at: http://www.international.gc.ca/csr counsellorconseiller rse/assets/pdfs/closing report-2012-03-ARG-rapport fermeture-eng.pdf (last accessed: 1 December 2012).
} 


\section{Private Member Bills: An Eclectic Mix of Legal Mechanisms}

In the wake of the voluntary federal CSR policy and the public regulation proposals put forward in the SCFAIT and Advisory Reports, individual Members of Parliament became engaged, introducing three different private members bills between 2009 and 2010 . While each of these intended to impact the accountability of Canadian mining companies operating abroad, the bills represent very different approaches to the regulation of the transnational corporation.

Liberal Member John McKay introduced the first of these in 2009 under the banner of Bill C-300, An Act Respecting Corporate Accountability for the Activities of Mining, Oil or Gas in Developing Countries. ${ }^{46}$ This Bill passed through its first and second reading at the House of Commons before it was narrowly defeated at its third and final reading in October of 2010. ${ }^{47}$ Many of the civil society organizations behind the Bill ${ }^{48}$ had also participated in the National Roundtables, either as Advisory Committee members or by making submissions. These groups made enormous efforts to garner political support for the Bill and they attributed its failure to heavy lobbying and misinformation on the part of the Canadian mining industry. ${ }^{49}$

Bill C-300 would have applied to any company incorporated under federal or provincial law that engaged in mining, oil or gas activities with support from the Government of Canada. Its stated intention was to ensure that the conduct of these companies is consistent with international environmental best practices and Canada's commitments to international human rights standards, defined as standards based on international customary law and on the international human rights conventions to which Canada is party. Concretely, the Bill required the creation of corporate accountability standards that incorporated the IFC Performance Standards, the Voluntary Principles, and human rights provisions consistent with international human rights standards.

\footnotetext{
${ }^{46}$ An Act respecting Corporate Accountability for the Activities of Mining, Oil or Gas in Developing Countries, Bill C300, first reading Feb. 9, 2009, available online at: http://www.parl.gc.ca/content/hoc/Bills/402/Private/C-300/C300 1/C-300_1.PDF (last accessed: 1 December 2012).

${ }^{47}$ CANADIAN NetWork On CORPORATE AcCountability, Bill C-300: Narrow Defeat despite Widespread Support for Mining Accountability and Human Rights (Oct. 28, 2010), available online at: http://cnca-rcrce.ca/bill-c-300narrow-defeat-despite-widespread-support-for-mining-accountability-and-human-rights/ (last accessed: 1 December 2012).

${ }^{48}$ CANADIAN NETWORK ON CORPORATE ACCOUNTABILITY, supra note 1.

${ }^{49}$ CANAdIAN NeTWORK ON CORPORATE ACCOUNTABILITY, supra note 47.
} 
Moreover, Bill-C 300 proposed a complaint mechanism administered by the Minister of Foreign Affairs and the Minister of International Trade. It would have obligated both Ministers to receive complaints from Canadian citizens, permanent residents, or residents and citizens from a developing country, regarding Canadian companies engaged in mining, oil or gas activities. Where either Minister determined that a corporation had not met the standard of conduct established pursuant to the Bill, they were to notify Export Development Canada (EDC) and the Canada Pension Plan (CPP) Investment Board.

Through a consequential amendment to the Export Development Act, ${ }^{50}$ Bill C-300 required EDC to make its contracts and transactions conditional on companies' compliance with the Bill's standards. Similarly, the Bill proposed an amendment to the Canada Pension Plan Investment Board Act ${ }^{51}$ requiring the Board to take the standards into consideration when investing CPP assets, and to refrain from investing in any corporation whose activities have been found by the Ministers to be inconsistent with the standards. Finally, through an amendment to the Department of Foreign Affairs and International Trade Act, ${ }^{52}$ the Bill further required DFAIT to undertake its duty to coordinate Canada's international economic relations and its efforts to expand Canada's international trade and commerce in a manner consistent with the standards. It also required DFAIT to refrain from promoting or supporting, beyond the provision of ordinary consular services, mining, oil or gas activities that are inconsistent with the standards set out by the Bill. Based on the foregoing, it is clear that Bill C-300 was modeled after the proposals in the SCFAIT and the Advisory Group Reports, while at the same time expanding their regulatory scope to include CPP investments and human rights standards.

The second private member's Bill in the realm of CSR in Canada is Bill C-323, An Act to amend the Federal Courts Act (international promotion and protection of human rights). ${ }^{53}$ New Democratic Party (NDP) Member Peter Julian first tabled this bill in 2009, but after the defeat of Bill C-300, he re-introduced it to Parliament again in $2011 .^{54}$ The Bill would extend the jurisdiction of the Federal Court and Federal Court of Appeal to include civil

\footnotetext{
${ }^{50}$ Export Development Act, R.S.C. 1985, s. 2 (f), available online at: http://laws.justice.gc.ca/eng/acts/E-20/ (last accessed: 1 December 2012).

${ }^{51}$ Canada Pension Plan Investment Board Act, S.C. 1997, available online at: http://lawslois.justice.gc.ca/eng/acts/C-8.3/ (last accessed: 1 December 2012).

${ }^{52}$ Department of Foreign Affairs and International Trade Act, R.S.C. 1985, s. 2, available online at: http://lawslois.justice.gc.ca/eng/acts/E-22/index.html (last accessed: 1 December 2012).

${ }^{53}$ An Act to amend the Federal Courts Act (international promotion and protection of human rights, Bill C-354, first reading Apr. 1, 2009, s. 14, available online at: http://www.parl.gc.ca/content/hoc/Bills/403/Private/C-354/C354 1/C-354 1.PDF (last accessed: 1 December 2012).

${ }^{54}$ PARLIAMENT OF CANADA, Legisinfo - Private Member's Bill C-323, available online at: http://www.parl.gc.ca/LegisInfo/BillDetails.aspx?Language=E\&Mode=1\&billld=5138027 (last accessed: 1 December 2012).
} 
claims brought by non-citizens who allege a violation, committed in a foreign state or territory, of international law or of a treaty to which Canada is a party. The Bill would then place the burden on the defendant to prove that the Courts should not take jurisdiction over the claim. Mr. Julian describes his Bill as a Canadian version of the U.S. Alien Torts Claims Act. ${ }^{55}$

The third private member's bill to date is Bill C-571, An Act respecting corporate practices relating to the purchase of minerals from the Great Lakes Region of Africa, ${ }^{56}$ tabled in 2010 by NDP Member Paul Dewar. ${ }^{57}$ It would apply to any corporation incorporated in Canada that endeavors to purchase minerals that originate in a designated group of African countries. The Bill would require companies to undertake certain due diligence practices to ensure that the purchase of these minerals does not directly or indirectly provide monetary gain to illegal armed groups. Finally, the Bill requires the CSR Counselor to report on those companies that she believes are not following appropriate CSR practices in the Great Lakes Region of Africa. In essence, Bill C-571 would expand the mandate of the CSR Office to include reporting on a specific issue and region.

\section{Analysis}

John Ruggie, the United Nations Special Representative on the issue of human rights and transnational corporations and other business enterprises, describes the "business and human rights predicament" in terms of a "governance gap". ${ }^{58}$ His usage of this term refers to the distance between the scope and impact of economic forces and actors, and the capacity of societies to manage their adverse consequences. On the other hand, Catherine Coumans, the Research Coordinator of the NGO MiningWatch Canada, ${ }^{59}$ describes the

\footnotetext{
${ }^{55}$ Peter JULIAN, Bill C-323, The International Protection \& Promotion of Human Rights Act / Projet de loi C-323, Loi de promotion et de protection des droits de la personne à l'échelle internationale (Oct. 5, 2011), available online at: http://peterjulian.ndp.ca/post/c-323-the-intl-protection-promotion-of-human-rights-act-loi-de-promotion-etde-protection-des-droits-de-la-personn (last accessed: 1 December 2012).

${ }^{56}$ Trade in Conflict Minerals Act, Bill C-571, first reading Sept. 30, 2010, available online at: http://parl.gc.ca/content/hoc/Bills/403/Private/C-571/C-571 1/C-571 1.PDF (last accessed: 1 December 2012).

${ }^{57}$ Since that time, this bill has not moved beyond the phase of introduction and first reading, see PARLIAMENT OF CANADA, Legisinfo - Private Member's Bill C-571, available online at: http://www.parl.gc.ca/LegisInfo/BillDetails.aspx?Language=E\&Mode=1\&billld=4663285 (last accessed: 1 December 2012).

${ }^{58}$ Special Representative of the Secretary-General on the issue of human rights and transnational corporations and other business enterprises, Protect, Respect and Remedy: a Framework for Business and Human Rights, ๆ 3, 104, U.N. Doc. A/HRC/8/5 (Apr. 7, 2008) (by John Ruggie).

${ }^{59}$ Catherine Coumans testified before the SCFAIT and was also a member of the National Roundtables Advisory Group, see HouSE of COMmons StANDING COMmitTEE ON ForeIgn AFFAIRS AND INTERNATIONAL TRAdE, supra note 27.
} 
same set of concerns in terms of the "effective impunity" of the transnational

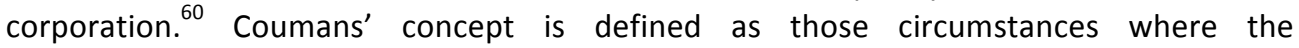
governments of the jurisdictions where companies operate (host states) do not hold them to account for their human rights violations, and the governments of the countries where companies are headquartered (home states) lack the political will to regulate them or provide the conditions for legal accountability for these violations. Interestingly, the term "impunity" does not appear in Ruggie's report, though Coumans does note that the "governance gaps" highlighted by Ruggie are one way of framing the causes of "effective impunity". 61

The above examples are only two of many that underscore the fact that there is no consensus on how to describe the legal and regulatory problematic generated by transnational corporate activity, with the Canadian mining industry's foreign operations given as one example. Indeed, how one frames the problem involves making choices that lead to different political, policy and legal proposals. Thus, there are at least two interrelated arenas for debate on the subject. The first is a conceptual, or even epistemic, debate about how to define the problem, while the second is a regulatory debate about how to address the problem, once defined.

The following analysis examines the regulatory and policy proposals advanced in Canada to date in order to identify the conceptual assumptions they embody regarding the state, the corporation, and civil society. This is an early stage attempt to interrogate the terms of the debate in Canada and the manner in which this debate has manifested in the particular legal terrain of law reform. To do so, this analysis gives special attention to the private and/or public features of each proposal, the specific way it purports to use law to structure the relationship between the state and the corporation, and the conception of the private and public spheres that underlie the regulatory dimensions of each proposal.

This method of inquiry illuminates the fact that, while on a political level it appears that the regulatory struggle in Canada has taken place between those who advocate enforceable standards and those who support exclusively voluntary commitments; there are also important conceptual differences and assumptions in the use of private and public law among the proposals for enforceable standards. As such, the proposals described in the previous section are analyzed in terms of three main categories: (1) public law regulatory approaches, (2) voluntary approaches, and (3) private law litigation approaches.

\footnotetext{
MiningWatch Canada was a key supporter of Bill C-300, see CANADIAN NETWORK ON CORPORATE ACCOUNTABILITY, supra note 1 .

${ }^{60}$ Coumans, supra note 32 , at 32-33.

${ }^{61}$ Coumans, supra note 32 , at $33,36$.
} 


\section{Public Regulation Models: What is the Scope of the Public?}

The SCFAIT Report, the National Roundtables Advisory Group Report, and Bill C-300 are all "public regulation" proposals for the reason that they envision either the creation of a new regulatory body, or the creation of new regulatory duties within an existing federal body. In either case, the designated body is charged with a regulatory mandate to investigate and evaluate the conduct of Canadian mining companies according to a set of standards, and to impose a certain range of sanctions where appropriate. Beyond sharing these public regulation features, these proposals are also unified by certain fundamental assumptions, which will be interrogated here in the context of two key regulatory features: standards and sanctions. At the same time, variations between proposals will be considered.

On the issue of standards, all three proposals aim to create a hybrid standard based on a blend of voluntary multi-stakeholder CSR standards and international public human rights law standards. However, the method for constructing this blended standard is contentious. One key issue that emerges from these three proposals revolves around the relative weight or prioritization that should be afforded to public sources of standards verses their private counterparts.

Of the three public regulation proposals, the Advisory Group Report is the most explicit and descriptive on the standards issue. The previous section described how this Report explicitly excluded public international human rights law as a source of standards in favor of transnational norms that originate from multi-stakeholder international processes. ${ }^{62}$ The Report confirms that this recommendation was a difficult concession for the civil society members of the Advisory Group. These members criticized standards originating from investment institutions, such as the IFC Performance Standards, as "risk-based principles developed by a financial institution and accepted by corporations". ${ }^{63}$ Civil society members would have preferred standards derived from human rights-based principles reflected in globally endorsed United Nations treaties. ${ }^{64}$

In response to these concerns, the Advisory Group Report stated that the application of transnational standards must "observe and enhance respect for" the principles of public

\footnotetext{
${ }^{62}$ The Advisory Group sanctioned the International Finance Corporation (IFC) Performance Standards and the Voluntary Principles on Security and Human Rights as the only appropriate sources of standards, in addition to the OECD Guidelines, already endorsed by the Government of Canada, see ADVISORY GROUP REPORT, supra note 13.

${ }^{63}$ ADVISORY GROUP REPORT, supra note 13 , at 12.

${ }^{64}$ Id. See also Coumans, supra note 32 , at $41-42$.
} 
international human rights law "that are within the sphere of control of companies". ${ }^{65}$ In other words, the standards contemplated by the Advisory Group must be consistent with only those human rights principles that are in Canadian mining companies' sphere of control. Conversely then, one might logically reason that, at least in some cases, these standards may in fact be inconsistent with human rights concerns that are outside of the sphere of control of companies. The Report seems to acknowledge this possibility when it concedes that its proposal does not cover the full range of human rights concerns raised by the extractive industry in developing countries. ${ }^{66}$ Unfortunately, the Report does not provide concrete examples that might better explain how its proposed blend of standards might work in practice.

At first brush, it would seem obvious that companies should not be held accountable for issues that are outside of their "sphere of control". Yet this simple proposition obscures the fact that the question of the scope of the human rights obligations of transnational companies under international law is extraordinarily complex and contentious. This precise issue has polarized several decades of efforts at the United Nations to create a code of conduct on the subject. ${ }^{67}$ By adopting the caveat "sphere of control", the language of the Advisory Group Report lends itself at best to a contractual conception of companies' human rights responsibilities. Legally speaking, the company might only be found to "control" those actions that are directly attributable to its employees or other agents with whom it enters into a contractual relationship of some kind.

The SCFAIT Report and Bill C-300 propose a method for blending international standards to create a Canadian CSR standard that stands in contradistinction to the Advisory Group Report's circumscription of the role of international human rights norms. However, on this subject, the SCFAIT Report makes only general recommendations. It simply states that company conduct should conform to clearly defined international human rights principles and corporate social responsibility standards. ${ }^{68}$ Bill C-300 provides some additional detail as to how such a combined standard might be constructed. Its declared objective is to ensure that Canadian mining companies operate in a manner that is consistent with Canada's obligations under international human rights law. However, in creating a human

\footnotetext{
${ }^{65}$ ADVISORY GROUP REPORT, supra note 13, at v. In its Report, the Advisory Group acknowledges that the initial recommended framework falls short of addressing the full range of issues of concern regarding extractive industry, particularly with regard to human rights, see id. at iv.

${ }^{66}$ Id. at iv.

${ }^{67}$ Alejandro Teitelbaum, Observations on the Final Report of the Special Representative of the UN Secretary General on the issue of human rights and transnational corporations and other business enterprises, John Ruggie, in Human RightS ANd SuStainable Human DEVELoPMENT, The Jus Semper Global Alliance (May 2011), available online at: http://www.jussemper.org/Resources/Corporate\%20Activity/Resources/Observations_to\%20Ruggies_final2011.pdf (last accessed: 1 December 2012).

${ }^{68}$ SCFAIT, supra note 26 , at 2.
} 
rights standard to meet this objective, Bill C-300 aims to incorporate the same set of multisectoral transnational standards that were given priority in the Advisory Group Report, namely, the IFC Performance Standards and the Voluntary Principles. As mentioned earlier, the IFC Standards are designed to govern the terms of the loans that the IFC provides to private enterprises investing in developing countries.

The prospect of melding this set of private transnational standards with international public law human rights principles is an interesting endeavor. Unfortunately, like the Advisory group Report recommendations, Bill C-300 was not implemented, making it difficult to conceptualize how this might occur in practice. Thus, these unfulfilled law reform projects leave a number of unanswered questions, which are briefly articulated here. First, it is unclear what an integrated private/public standard might achieve, beyond what is already accomplished by international public law norms. This question arises given that public law principles are generally far more expansive than private transnational norms. Moreover, to the extent that there are differences between the two, it may be the case that risk-based standards and human rights-based norms contain certain fundamental contradictions. This seemed to be the concern of the civil society members of the Advisory Group. CSR standards are designed to be compatible with protecting and advancing the interests of investors, while international human rights standards were created to grant protections to all individuals. This raises the question of how standards rooted in different normative logics might be combined, and what logic might orient the resulting blended standard. For example, how would the interests of communities affected by mining operations be reconciled with those of the investors in the design of this blended standard?

This question leads to another important, and related, area of analysis, namely the relationship between the standards and objectives articulated in these regulatory proposals. Both the SCFAIT Report and Bill C-300 shared a common objective: to ensure that the conduct of Canadian companies' is consistent with Canada's international human rights standards. Thus, both proposals would impose a duty on the Canadian government to regulate the activities of its mining companies abroad to meet this objective. In such a regime, the Canadian state would impose its obligations under international human rights law onto these companies. Further, the regulation contemplated would extend the scope of these obligations to include communities adversely affected by Canadian mining companies operating abroad. In sum, the Canadian state would have an obligation, created by the regulation, to ensure that its companies do not violate the rights of communities abroad, as articulated by the international treaties that Canada is signatory to. ${ }^{69}$

\footnotetext{
${ }^{69}$ For an argument that the Canadian state has a duty in international law to regulate in this regard, see Sara Seck, Home State Responsibility and Local Communities: The Case of Global Mining 11 YALE HUM. RTS. \& DEV. L.J. 177 (2008).
} 
This careful (if not laborious) articulation reveals the close relationship between standards and objectives in regulatory design. For example, in both Bill C-300 and the SCFAIT Report, the standards also constitute the objectives of the proposed regulation: the objective is to ensure that companies respect human rights, and the standards imposed on companies are human rights standards. Thus, standards and objectives are crucial to the design of these public regulatory regimes and they must inform this article's analysis of their proposed sanctions. This is the case because the sanction components of these regulatory regimes constitute the means for achieving their objectives, which are in turn contingent on the standards they apply.

Turning then to the issue of sanctions, the SCFAIT, Advisory Group and Bill C-300 all concentrate on the withdrawal of federal government financial and political support. As the first proposal, the SCFAIT Report set a template in this regard that was subsequently followed by the other two proposals. While the SCFAIT Report puts forward a model that targets the institutional financing of Canadian mining companies, it refers to only two sources of financing: private sources originating from international financial institutions (IFIs), and public financing from funds managed by the Canadian government, primarily through Export Development Canada (EDC). Thus, it locates the enforceable standards it proposes in two spheres, namely transnational private law and domestic public law. Since the Canadian government lacks the power to unilaterally make changes in IFI financing, its proposal regarding public financing is of greater interest for the purpose of this analysis.

What is notable about SCFAIT's adoption of financing as a method of sanction is the narrowness of its focus, as in fact the most significant areas of company financing are absent from the Report. There is no question that the accumulation of capital through financial markets in Canada is the largest source of financing for Canadian mining companies, as outlined above. At $\$ 58$ billion in $2010,{ }^{70}$ the outward investments of Canadian mining companies dwarfs the total investments of EDC in the entire commercial extractive sector, at $\$ 14.6$ million in the same year. ${ }^{71}$ Yet the SCFAIT Report does not consider Canadian capital markets whatsoever.

Ostensibly, this is because the Report is concerned only with the federal government's "political and financial support" for Canadian mining companies. If so, the Report's rationale is predicated on the assumption that government political and financial support does not occur in and through the private sphere, or in other words, that financial markets

\footnotetext{
${ }^{70}$ Stothart, supra note 2 , at 82.

${ }^{71}$ EXPORT DeVElopment CANADA, Annual Report 2011, Supplemental Information - Table 6: Concentration of Exposure by Industry, available online at: http://www19.edc.ca/publications/2012/2011ar/english/11-1-6.shtml (last accessed: 1 December 2012).
} 
exist autonomously of state decisions, actions, and interventions. ${ }^{72}$ By rending invisible the multidimensional role of government in the creation, maintenance and promotion of capital markets, ${ }^{73}$ the SCFAIT Report precludes the market, as an area of possible intervention and sanction, from the scope of the state's regulatory authority.

This assumption that the market exists autonomously from the state fits with the SCFAIT Report's related conception of the public sphere and the scope of moral responsibility attributable to the state. As described above, the Report focuses almost exclusively on the financing provided by EDC, a corporation created and owned by the Government of Canada. The Minister for International Trade appoints EDC's board members, who must report to Parliament annually on the fulfillment of EDC's primary objective, which is to develop Canadian capacity to engage in trade, partly through the provision of credit, insurance and investments to Canadian businesses. ${ }^{74}$

By focusing exclusively on EDC, the SCFAIT Report circumscribes the role of the Canadian State in the regulation of Canadian mining companies operating abroad to circumstances where it has entered into a direct contractual relationship with a company in the form of a financing agreement. Seen as such, the role of the state as a regulator is reduced to a private market actor in that the scope of its regulatory authority is dictated by its market relationships, in this case as an issuer of loans. Given that human rights and other normative concerns form the objectives of SCFAIT's proposed regulatory approach (as discussed above), this method of sanction serves to equate the state's sphere of moral responsibility with the circumstances of its direct financial interests. Thus, this public regulation approach is "market-based" in the sense that the state, while apparently acting as a public regulator, regulates only its own market-based relationship with private commercial actors.

The Advisory Group Report maintained the SCFAIT Report's underlying assumptions regarding the nature of the private and public sphere and their relationship. Like the SCFAIT Report, it focuses on conditioning the federal government's project financing, primarily through EDC. However, it somewhat minimizes the regulatory role proposed in the SCFAIT Report in that it does not contemplate a requirement that projects be screened

\footnotetext{
${ }^{72}$ For some examples of contributions that attempt to reveal the political/policy decisions involved in creating different aspects of the market, see David Kennedy, Some Caution About Property Rights as a Recipe for Economic Development 1 Acc., ECON., \& L. 1 (2011); ANNELISE RILES, CollaterAL KNOWLEDGE: LEGAL ReASONING IN THE GLOBAL FInANCIAL MARKetS (2011); Robert L. Hale, Coercion and Distribution in a Supposedly NonCoercive State 38 POL. SCI. Q. 470 (1923); Morris R. Cohen, Property and Sovereignty 13 CORNELL LAW Q. 8 (1927).

${ }^{73}$ Of course the constitutional division of powers between the federal and provincial governments in Canada determines to some extent which level of government performs what role in the creation and maintenance of Canadian financial markets.
}

${ }^{74}$ Export Development Act, supra note 50, at ss. 3-5, 10, 11. 
prior to financing. ${ }^{75}$ Rather, it specifies that financing may only be withdrawn after a complaint process is completed, and compliance efforts are exhausted. Further, the Advisory Group does not take up the SCFAIT recommendation to pressure international financial institutions to enhance the enforcement of CSR standards.

On the other hand, the Advisory Group shares the SCFAIT recommendation to use the withdrawal of political support as a potential sanction. It elaborates on the meaning of political support, which was not expounded on in the SCFAIT Report, and defines it as support from trade missions that goes beyond ordinary consular services by promoting a Canadian company or its interests in a foreign country. In sum, the strength of the public regulatory role in the Advisory Group Report is somewhat weaker than in the SCFAIT proposal, support for the enforcement of transnational norms is removed, and the meaning of political support is defined.

On the subject of sanction and financing, the regulatory vision of Bill C-300 most closely resembles that of the SCFAIT Report. It contemplates imposing a proactive obligation on EDC to screen projects, together with the withdrawal of access to EDC financial services. It further adds specific provisions for the withdrawal of Canadian political support, building on the definition set out in the Advisory Group Report. However, Bill C-300 moved significantly beyond both Reports in that it introduces an additional form of sanction through the requirement that investments be screened, and that CPP funds be withdrawn from Canadian mining companies found responsible for human rights violations abroad. This step is momentous in terms of its potential economic ramifications. The CPP is unquestionably the largest institutional investor in Canada. ${ }^{76}$ As of June 2012, the CPP Fund was valued at $\$ 165.8$ billion, ${ }^{77}$ affording it a level of investment power that dwarfs that of EDC, with a cap of authorized capital set at $\$ 3$ billion. $^{78}$

Normatively, Bill C-300's proposal would have transformed the CPP Board's current framework for investment decision-making. At present the Board, like all other public sector pension fund investment boards in Canada, operates in a legal framework that allows it to take social and environmental considerations into account in its investment decisions only to the extent that they threaten to negatively impact a company's

\footnotetext{
${ }^{75}$ In spite of this, the Advisory Group Report does contain recommendations that call on Export Development Canada to improve its disclosure policy, see ADVISORY GROUP REPORT, supra note 13, at vi, 19.

${ }^{76}$ In fact, large institutional investors such as pension funds account for over one-third of the world's invested assets, see Foreign AfFaIRS AND INTERnAtIONAL TRADE CANAdA, Corporate Social Responsibility, Financial Incentives (Mar. 2009), available online at: http://www.international.gc.ca/trade-agreements-accords-commerciaux/ds/csrstrategy-rse-stategie.aspx?view=d (last accessed: 1 December 2012).

${ }^{77}$ CPP INVESTMENT BOARD, available online at: http://www.cppib.ca (last accessed: 1 December 2012).

${ }^{78}$ Export Development Act, supra note 50, at s. 11.
} 
profitability. ${ }^{79}$ The Board explicitly states that it does not screen its investments based on these concerns alone for the reason that doing so would either increase risks or reduce returns. Rather, the Board evaluates these concerns only to the extent they affect longterm risk and financial returns to beneficiaries. ${ }^{80}$

The Board's statements in this regard make it clear that Bill C-300's proposal represents a significant incursion of human rights concerns into the market place. While legislative measures of this nature are not unprecedented globally, they would have been the first of their kind in Canada. ${ }^{81}$ Albeit only in the realm of CPP investments, Bill C-300 advances the proposition that the state may impose human rights (moral) parameters onto private investment decision-making processes that are not necessarily compatible with optimizing investors' returns. In what sense are these decisions private? Of course the CPP is a public pension fund, and like the EDC, the CPP Board is a Crown corporation, accountable to Parliament, though in this case it's members are appointed by the federal Minister of Finance. ${ }^{82}$ However, there is a significant conceptual difference between the proposal to withdrawal EDC loan support and the idea of constraining CPP investments. The latter of these expands the scope of the state's moral and regulatory concern to include the decisions made by the investment administrators of Canada's national pension fund on behalf of pension plan beneficiaries. Whereas in the case of EDC the state's financial

\footnotetext{
${ }^{79}$ For the statutory description of the CPP Board's duties, see Canada Pension Plan Investment Board Act, S.C. 1997, s. 14, available online at: http://laws-lois.justice.gc.ca/eng/acts/C-8.3/ (last accessed: 1 December 2012). For the common law definition of fiduciary relationship, see Hodgkins v Simms, 117 D.L.R. (4th) 161 (1994). The CPP Board is generally understood to have a fiduciary relationship in law with CPP beneficiaries that prevents it from taking human rights concerns into account that might negatively affect financial returns, see Benjamin J. Richardson, From Fiduciary Duties to Fiduciary Relationships for Socially Responsible Investing: Responding to the Will of Beneficiaries, 1 J. OF SUST. FIN. \& INV'NT. 5, (2010). The CPP is a signatory to the United Nations-backed voluntary Principles for Responsible Investment. The Principles declare that, "as institutional investors, we have a duty to act in the best long-term interests of our beneficiaries. In this fiduciary role, we believe that environmental, social, and corporate governance (ESG) issues can affect the performance of investment portfolios". Signatories of the Principles "publicly commit to adopt and implement them, where consistent with our fiduciary responsibilities." See PRI SECRETARIAT, The Principles of Responsible Investment, available online at: http://www.unpri.org/principles/(last accessed: 1 December 2012).

${ }^{80}$ CANADIAN PENSION PLAN INVESTMENT BOARD, 2011 Report on Responsible Investing, at 23, available online at: http://www.cppib.ca/files/PDF/CPPIB_RI_Report.PDF (last accessed: 1 December 2012).

${ }^{81}$ For example, the Swedish, Norwegian, New Zealand and French national pension schemes are statutorily required to invest responsibly, see Benjamin J. Richardson, Protecting Indigenous Peoples through Socially Responsible Investment 6 I.L.J. 1, 29 (2007). A recent example of divestment based on a country's human rights record occurred in 2006/2007 in California when the state government introduced the California Public Divest from Sudan Act, Cal. Gov. Code § 7513.6 (2012), available at: http://law.onecle.com/california/government/7513.6.html (last accessed: 1 December 2012), and the California Public Divest from Iran Act, Cal. Gov. Code $\S 7513.7$ (2012), available at: http://law.onecle.com/california/government/7513.7.html (last accessed: 1 December 2012).
}

${ }^{82}$ Canada Pension Plan Investment Act, supra note 78, at ss. 2, 3, 10. The Board is also accountable to provincial Ministers, see s. 50. 
interests are at stake in its capacity as a lender and owner of EDC, in the case of the CPP, the state is intervening in reference to the private financial interests of 18 million Canadian CPP beneficiaries.

While Bill C-300 significantly expands the economic scope of regulatory intervention, it maintains a certain conceptual consistency with the SCFAIT and Advisory Group Reports. All three proposals share a common focus on withdrawing financial support in the form of market investments or loans as their chosen method of regulatory sanction. However, it is unclear how these sanctions will meet the express objectives embodied in the standards discussed above. More specifically, it is not obvious that the withdrawal of access to EDC loans and CPP investments alone has the potential to meet the objectives of the proposed regulation, namely to ensure that the conduct of Canadian mining companies is consistent with Canada's human rights obligations in international law.

Moreover, where problematic mining operations have occurred or continue, the withdrawal of these forms of financial support provides no apparent remedy to affected communities, who are nonetheless the presumed rights-holders in the regimes proposed by the SCFAIT Report and Bill C-300. Given the robust standards and objectives created by these two proposals in particular, it is conceptually unclear why the scope of the federal government's regulatory authority and moral concern should be limited to its role as a lender through EDC, or as the facilitator of pension investments through the CPP. While these roles are no doubt important and carry economic and moral weight, they do not subsume the extent of the government's role in the formation and maintenance of Canadian markets and, as a corollary, in the operation of Canadian mining companies.

\section{The Federal CSR Policy: Civil Society as a Source of Risk?}

As indicated above in Part B, the federal government's CSR policy represents a total aboutface from the public regulation proposals recommended in the Advisory Group and SCFAIT Reports, toward an approach based entirely on multisectoral norms and voluntary commitments. First, while the CSR policy adopts the private transnational standards recommended in the Advisory Group Report, it omits any reference to public international human rights law. Second, it disregards both Reports' recommendations to create an investigative regulatory mechanism, linked with a possible sanction in the form of the withdrawal of federal financing. Instead, it creates a voluntary mediation service.

In light of these two features, the federal CSR policy communicates a particular view of the Canadian State that is distinct from that of the public regulation proposals. It frames the state, not as a regulator of the human rights impacts of market activities, but rather as a mediator of conflicts between private parties. Concomitantly, it presumes that the state's commercial relationships with the private sector in the form of financing are immune from moral or human rights concerns. Moreover, to govern mediation between companies and 
civil society actors, it predominantly selects norms that originate from private sources, developed in a risk-based investor-oriented framework. ${ }^{83}$ The dominance of such norms in the federal CSR review process would seem to be at odds with the fact that the civil society actors who are intended to use the process are generally not in an investor relationship with the company. This returns us to some of the concerns and unanswered questions raised in the previous section with regard to blending private and public norms.

Also notable is the apparent incoherence of the state's mediator role envisioned in the CSR policy. The policy declares that the Office of the CSR Counselor is an "impartial advisor and facilitator" and "an honest broker". ${ }^{84}$ Yet at the same time the stated purpose of the policy is to "improve the competitiveness of Canadian international extractive sector companies by enhancing their ability to manage social and environmental risks." ${ }^{85}$ It is difficult to comprehend how the Office of the Counselor might be impartial when it also forms part of an overarching policy with the primary objective of improving the situation of Canadian companies. The policy contains no counter-balancing objective oriented toward improving the situation of those actors who might be adversely affected by companies. ${ }^{86}$ Rather, the language employed to articulate the policy's purpose suggests that it considers that the concerns of communities and individuals that might be raised in the review process are "risks" that must be "managed" for the benefit of the company. Thus, although at a technical or procedural level the review process may appear to be "fair" or "impartial", when placed in the context of its overall policy objectives, this become debatable.

\footnotetext{
${ }^{83}$ These are the IFC's Performance Standards, which govern the terms of loans made by the IFC, and the Global Reporting Initiative (GRI), with an original target audience of investors, see GLOBAL REPORTING INITIATIVE, What is GRI?, available online at: https://www.globalreporting.org/information/about-gri/what-is-GRI/Pages/default.aspx (last accessed: 1 December 2012). The Voluntary Principles are based on human rights principles but only apply to the area of security. The OECD Guidelines were not developed in a risk-based framework, however prior to the introduction of its CSR policy, the Canadian government had already adopted these voluntary guidelines as an OECD member and through the Canadian National Contact Point.

${ }^{84}$ Foreign AfFaIRS AND INTERNATIONAL TRADE CANADA, The Review Process, available online at: http://www.international.gc.ca/csr_counsellor-conseiller_rse/review_process-processus_examen.aspx?view=d (last accessed: 1 December 2012).

${ }^{85}$ Foreign AfFAIRS AND INTERNATIONAL TRADE CANADA, About Us, available online at: http://www.international.gc.ca/csr_counsellor-conseiller_rse/About_us-A_propos_du_bureau.aspx?view=d (last accessed: 1 December 2012).

${ }^{86}$ The policy's first pillar involves supporting initiatives to enhance the capacity of developing countries to manage the development of extractive activities and improve economic development. However, there is no clear link made between this objective and the concerns of communities and individuals adversely affected by a Canadian company. The fact that economic development in the form of resource extraction does not necessarily translate into an improved situation for mining-affected communities is well documented in the resource curse literature. See for instance, Paul Collier, Laws and Codes for the "Resource Curse" 11 YALE HUM. RTS. \& DEV. L.J. 9, (2008); Matthew Genasci \& Sarah Pray, Extracting Accountability: The Implications of the Resource Curse for CSR Theory and Practice 11 YALE HUM. RTS. \& DEV. L.J. 37, (2008); Jeffery D. Sachs \& Andrew M. Warner, Natural Resources and Economic Development: The Curse of Natural Resources 45 EUR. ECoN. R., 827 (2001); Michael L. Ross, The Political Economy of the Resource Curse 51 WORLD POLITICS 297, (1999).
} 
The claim to fairness and impartiality is further called into question by the terms of the mediation services offered. The CSR policy allows a company to request a review of civil society actors who it "believes" have raised unfounded allegations. To date this form of review is unprecedented in a CSR mechanism. On its face, it appears to be based on a formal proceduralist concept of fairness in the sense that it allows either opposing party to complain about the other. However, this gesture toward equal treatment is immediately complicated by the policy's language describing parties' eligibility for the review process. It requires that civil society actors hold a "reasonable belief" in the substance of their concern, while the company is only required to "believe" that a party has made unfounded allegations. $^{87}$

Most significantly, the federal CSR approach diverges dramatically from the definition of "the problem" put forward in the SCFAIT and Advisory Group Reports' recommendations to Parliament, namely law reform in Canada to address the concern that the activities of Canadian mining companies in developing countries conform to human rights standards. ${ }^{88}$ In contrast, the federal CSR policy adopts a very different conception of the fundamental nature of the problem. Namely, it seems to view civil society actors as the problem. These actors are understood as a source of risk to companies to the extent that they express either good faith concerns or unfounded allegations regarding company behavior. Notably, in the view of the federal government, this latter source of risk is such a significant problem that it merits state intervention in the form of the review process and mediation service offered by the Office of the CSR Counselor. This is surprising, not only because this issue is not mentioned in either the SCFAIT or the Advisory Report, but also because it presumes that companies lack other adequate avenues for raising concerns of this nature. $^{89}$

In sum, the federal CSR policy appears to completely invert the orientation of the public regulation proposals. Rather than reflecting a concern for the human rights consequences of Canadian mining activities for local communities, it conceives of these communities and other civil society actors as a potential source of risk to Canadian mining companies'

\footnotetext{
${ }^{87}$ The Office of the Extractive Sector Corporate Social Responsibility Counsellor, Government of Canada, Rules of Procedure for the Review Mechanism of the Office of the Extractive Sector Corporate Social Responsibility (CSR) Counsellor (October 2012), at 4, available online at: http://www.international.gc.ca/csr counsellorconseiller rse/assets/pdfs/rules_procedure-regles procedure-eng.pdf (last accessed: 1 December 2012).

${ }^{88}$ ADVISORY GROUP REPORT, supra note 13 , at 2.

${ }^{89}$ For example, two defamation suits were recently brought in Canada by Canadian mining companies against journalists and academics who published research critical of these companies, see CANADIAN ASSOCIATION OF University TeAChers (CAUT) Bulletin, Noir Canada Defamation Lawsuit Settled, Publication of Book Stopped (Nov. 2011), available online at: http://www.cautbulletin.ca/en article.asp?articleid=3342 (last accessed: 1 December 2012).
} 
success and profitability. This view might explain why the Office of the CSR Counselor has garnered such little interest from civil society actors, having registered only three complaints against mining companies in two years. On the other hand, its services have yet to be used by mining companies to express concerns of unfounded allegations. Whatever the reasons for this lack of interest in both sides, what is certain is that its relevancy as a mediation service has yet to be demonstrated.

It should be noted that the federal CSR policy is also the subject of Bill C-571. This Bill intends to create a special focus within the mandate of the CSR Counselor on the specific issue of companies' possible complicity with illegal armed groups in certain African countries. However, it does not modify the review process and simply requires that the CSR Counselor report on this specialized subject matter. As such, the provisions of Bill C571 do not contain material that might modify or enrich the above analysis.

\section{Private Law Cause of Action: A Loss of Faith in the State as a Regulator?}

The provisions of Bill C-323 are simple but with potentially far-reaching consequences. It gives the Federal Court and Federal Court of Appeal jurisdiction over a violation of international law committed in a foreign state against someone who is not a citizen of Canada. While the scope of this Bill clearly goes beyond this paper's focus, for the purposes of the subject matter at hand, it would entail that a community or individual in a foreign state could bring a private action in Canada against a Canadian mining company for the violation of its rights, as recognized by the international human rights treaties to which Canada is party. In fact, based on the political support being marshaled for Bill C-323, the application of the Bill to the Canadian mining sector is actually one of its primary objectives. $^{90}$

Like Bill C-300 and the SCFAIT Report, Bill C-323 intends to impose international human rights law obligations directly onto Canadian companies. However, unlike these public regulation proposals, Bill C-323 does not try to create a blended standard; instead it would simply apply public international law. Moreover, the Bill does not concern itself with company financing. Rather, in the framework of a civil claim, it contemplates a monetary sanction that would also serve as a remedy for victims, assuming that they are able to effectively enforce such an order.

\footnotetext{
${ }^{90}$ The Bill's sponsor, Member of Parliament Peter Julian, organized a conference in support of the Bill, held on 16 March 2012 in Ottawa. The subject matter of this conference focused exclusively on Canadian companies' operations abroad, particularly in the area of mining, and the impacts on communities. See Peter Julian, Walking the Talk: Human Rights Abroad, Take II (Mar., 16, 2012), available online at: http://peterjulian.ndp.ca/conferenceagenda-programme (last accessed: 1 December 2012).
} 
Although Bill C-323's proponents compare it to the Alien Tort Claims Act (ATCA) ${ }^{91}$ in the United States, it contains at least one significant difference, namely it reverses the traditional burden of proof on the question of jurisdiction, thereby creating a presumption in favor of extra-territorial jurisdiction. Typically in international tort actions, claimants must prove that the court considering the claim has jurisdiction according to the international private law doctrine of forum non-conveniens. This burden has created a significant barrier to claims brought in the United States ${ }^{92}$ under the ATCA, as well as in Canada $^{93}$ under existing common law tort causes of action. Having created a presumption of jurisdiction, Bill C-323 would presumably make it relatively easier for claimants to access Canadian courts.

On its face, Bill C-323 appears to resolve many of the concerns raised by the foreign operations of Canadian mining companies. It would theoretically include every violation conceivably captured by the full range of Canada's international human rights obligations. Further, it would hold Canadian companies to account in a proceeding with the potential to provide a remedy to the victims. Of course, on the other hand there are potential practical disadvantages to addressing these issues through private civil claims. These claims, even when successful, do not necessarily prevent or halt human rights violations; rather the "injuries" incurred are simply quantified in monetary terms and, as with any civil claim, there is a danger that the cost of litigation simply becomes part of the "cost of doing business" for the corporation.

Perhaps Bill C-323 appears to be so effective in resolving some of the issues raised in this paper because it entirely avoids the question of regulation. It does not create a regulatory duty of any kind for the Canadian state with regard to either the corporation or civil society. Rather, it constructs a direct relationship of human rights obligations between these latter two entities. The problem at hand becomes an issue between two private parties, the corporation and the community, yet ironically this conflict is governed by the state's international human rights commitments. The state is not present, while its commitments are.

\footnotetext{
${ }^{91}$ Alien Tort Claims Act, 28 U.S.C. § 1350 (2006).

${ }^{92}$ In the United States, as of 2004 there were approximately twelve active cases against corporate defendants under the ATCA, only three or four of which had survived a motion to dismiss on the basis of jurisdiction. Most of the ATCA cases against private corporations have been dismissed for lack of jurisdiction and none have resulted in a final judgment against a U.S. corporation: Harold Hongju Koh, Separating Myth from Reality about Corporate Responsibility Litigation, 7 J. OF INT'L ECON. L. 263, 269-70, 298 (2004).

${ }^{93}$ In Canada the courts have adopted such a narrow approach to the doctrine of forum non-conveniens that most litigants have been unable to convince the courts to take jurisdiction over the harm allegedly caused by a Canadian mining companies abroad. Recherches Internationales Quebec v. Cambior Inc., [1998] Q.J. no 2554 (Can. Que. Sup. Ct. J.); Anvil Mining Limited v. Association canadienne contre l'impunité, [2012] J.Q. no 368, 2012 QCCA 117 (Can. Que. Ct. A.). For a review of these cases, see Webb, supra note 15, at 48-52; Imai, Maheandiran \& Crystal, supra note 19.
} 
By eliminating the state from the equation, in a certain sense Bill C-323 represents the privatization of the problematic discussed in the opening of this paper. As such, a question lingers in the face of the Bill's aspiration for legal accountability. If the state's commitments in international human rights law are to govern, why not require it to act or regulate in order to ensure that these commitments are fulfilled? Perhaps the question of the relationship between the state and the market has become too complex to tackle, and the issues are better resolved by court-awarded damages in private actions. Or perhaps civil society proponents have calculated that the political conditions necessary to support a program of effective regulation are simply absent. In either case, it may be that Bill C-323 signals a certain loss of faith in the possibility that the Canadian state might act to regulate the activities of Canadian mining companies operating abroad.

\section{E. Conclusion}

The above analysis of the public regulation proposals reviewed raises two key themes that provide fodder for further research and reflection. The first relates to these proposals' aspiration to blend private risk-based CSR norms with international public law human rights principles. While this paper raised several questions in response to this possibility in the abstract, it also observed that in the concrete example provided by the Advisory Group Report, the use of the term "sphere of control" seems to reduce the application of public international human rights law to the sphere of companies' contractual relationships.

The second key theme relates to the view taken in these proposals of the Canadian state and its relationship with the market. The common vision of public regulation that emerges focuses on federal government contracts with companies through EDC. By reducing the discussion of "government support" to a question of loan financing, these proposals take a market-based view of the state that equates its potential regulatory and moral responsibilities with its contractual relationships. Even where "government support" is expanded to include CPP investments as in the case of Bill C-300, the assumptions that the market is autonomous of the state, and that the state's regulatory obligations are dictated by market relationships, remain intact.

The dominance of contractual and investment rationales in the public regulation proposals reviewed here is ironic given the political perspectives and aspirations of their civil society proponents and activists. These groups passionately seek to prevent and remedy human rights violations committed against communities in developing countries and to hold Canadian mining companies to account in this regard. Yet each of the proposals contains a certain disjunction between its broadly stated human rights standards and objectives, and the market-based sanction or method chosen as a means for achieving this objective. Given the economic and social context described in this paper's introduction, it remains doubtful whether or not the financing and investment sanctions proposed would be 
capable of "holding companies to account" and "ensuring that their conduct is consistent with human rights obligations", to use some of the language of the SCFAIT Report and Bill C-300. ${ }^{94}$

In the midst of what may be a highly conceptual and abstract analysis, I realize that the people behind these public regulation proposals operate within the constraints of what is politically possible. Faced with a particular political scenario and propelled forward by their conviction to act, they are not bound simply by conceptual issues. This paper is after all, a "critical legal account" of the law reform events it depicts. There is no doubt that a "critical social account" would reveal the fascinating and sophisticated political calculations and trade-offs that activists' undertook to advance each of these law reform proposals the great distances that they ultimately achieved.

As stated at the outset, this paper springs from a broader research project concerned with the dynamics of law and social change in general, and in particular with the use of law as a method of resistance "from below" to dominate models of economic globalization. The question that drives this research is how the law might be of use to those who do not benefit, or who do not benefit equitably, from the activities associated with economic globalization. The law reform proposals reviewed here indicate that this line of questioning necessarily requires an examination of activists' engagement with private and public law mechanisms. This paper represents a preliminary step toward considering how the private or public nature of the legal forum might shape activists' legal strategies and articulations of the corporation, the state and the problem.

To explore this question more fully, the theories of action, resistance and social change that animate these strategies must be clearly identified. These theories must be built on a conception of the relationship between legal activism and the social change it pursues. Further, the concepts of the state and the corporation that are implicit or explicitly present in the arguments and legal frameworks employed by these strategies must be uncovered. Perhaps the tentative lesson learned from this case study is that in order to approximate human rights aspirations through the regulation of Canadian mining companies operating abroad, critical research and thinking is required to elucidate the full extent of the relationship between the Canadian state, the market, and Canadian mining companies. Indeed, the aspiration of any activist-oriented conceptual reflection, such as the one pursued here, is to make a contribution capable of informing political strategy and innovation.

\footnotetext{
${ }^{94}$ HOUSE OF COMmons StANDING COMmitTEe ON FoREIGN AfFAIRS AND INTERNATIONAL TRADE, supra note 27 at 2-3; An Act respecting Corporate Accountability for the Activities of Mining, Oil or Gas in Developing Countries, supra note 45, s. 3.
} 
Looming in the background of this discussion is the specter of the Canadian CSR Policy, which sends the disconcerting signal that the federal government of the day views civil society as the problem or, stated in market terms, as the source of risk. The present challenge to this policy is the total pragmatism represented by Bill C-323, where the state, and any concomitant regulatory question, is eliminated in favor of the effective privatization of the issues in the form of a legislated civil law cause of action. We can only hope that this (mis)alignment of visions does not allude to a loss of faith in the possibility of engaging productively with the regulatory questions that are crystallized by the contemporary foreign operations of Canadian mining companies. 